\title{
沖縄から見る世界秩序の変動 一「最前線」からの報告
}

佐藤学

\section{沖縄の位置}

\section{（1）二つの言説}

沖縄の地理的、社会的「位置」に関して、二つ の相反する言説が広く語られる。一つは、沖縄が、 日本にとっての東アジア諸国への玄関口であり、 文化交流、経済・交易の中心たりうる、という 明るい展望である。もう一つは、沖縄は、米ソ 冷戦時の、重要な米軍の前方展開基地であり、 現在は、対中「新冷戦」の最前線である、とする 危機言説である。

前者には、沖縄の歴史に基づく、アジア諸国 との、「日本」とは異なる位置づけが含まれる。 すなわち、琉球王国が形式的には、17世紀初め の薩摩侵攻から明治政府による琉球処分、廃琉 置藩、廃藩置県に至るまで、独立国として存在し、 その間、日中両属のバランスの下で生き延びた 歴史であり、また、第二次世界大戦後の米軍施 政下の経験である。

後者は、日本の中心部から遥か西南に位置す る外洋離島として、米軍基地の島として「自由 使用」されてきた第二次世界大戦後のあり方に 根差す。朝鮮戦争を機に、米軍は沖縄を基地所 在地として重要視し、ヴェトナム戦争時には、 空軍嘉手納基地が「北爆」のための B 52 出撃基 地として使われ、また、この時期、沖縄は、陸軍、 海兵隊の地上部隊をヴェトナムに送り出す機能 を負わされ、冷戦下における米軍事行動の最前
線に立たされた。

ヴェトナム戦争からの米軍撤退、その後の冷 戦終結から長い時間が経ったにもかかわらず、 「東アジアには冷戦構造が残されている」ため と、在沖米軍基地の本格的縮小は実現せず、今 は、対中国新冷戦突入が言われ、沖縄は、尖閣 諸島という潜在的紛争地を抱えるために、再び、 軍事対立の最前線に立たされている。

\section{（2）「潜在的紛争地」の条件}

一歩引いて考えれば、沖縄は、(1)国家の地理 的周縁部にある、(2)過去に主権、施政権が、主 要国の間で動いている、(3)国家中心部とは異な る文化的伝統を持つ、という条件の下にあり、 これは典型的な紛争地の条件、紛争地にされる 条件ではないか。

朝鮮戦争時には、沖縄の米軍基地建設は、ま だ途上であり、ソ連、中国が沖縄に軍事攻撃を 実施する可能性は低く、領土をめぐる軍事紛争 の場面となることは考えられなかった。

ヴェトナム戦争においては、米軍の前方展開 基地として、沖縄島全体が使われ、ヴェトナム 戦争に「当時者」として関わらされた。兵員の 「慰安」の場としての社会的負担も含めてであ る。しかし、北ヴェトナムが、北爆の発進基地 である米空軍嘉手納飛行場を攻撃する能力は到 底なく、ソ連は、自身の米国との直接軍事対決 を避けるために「冷戦構造」を構築したのであ 
り、ソ連が在沖米軍に直接攻撃をすることも考 えられなかった。米ソ冷戦下の沖縄は、重要な 米軍の軍事拠点であり戦争に直接関与させられ たが、沖縄自体が戦争の場となる可能性は極め て低かった。

\section{（3）尖閣問題}

現在の米中「新冷戦」懸念が高まる中での沖 縄の地位はどうか。日本が実効支配している尖 閣諸島をめぐる軍事的緊張が2000年代に顕在化 している。尖閣諸島の領有権をめぐる対立に関 して、経済的価值のない無人島の領有権争いが、 本格的な軍事対決にはならないとする捉え方が 一般的であった。中国が尖閣諸島の領有権を主 張し始めたのは、沖縄施政権返還と時を同じく して、尖閣諸島海域に海底油田が発見され、そ の資源を狙っての行動と見られてきた。ところ が領土問題には、ナショナリズムという抑制困 難なワイルド・カードが入ってくる。さらに、 尖閣諸島の領有権は、台湾も主張しており、そ こには台湾問題も加わる。

それでも、「尖閣問題」が日中台の間に収まっ ていた内には、沖縄の軍事的危機の可能性は、 まだ低かった。

\section{（4）在沖米軍}

日本では、在沖米軍、特に海兵隊が、尖閣防 衛部隊として機能するはずという期待が強く、 それが海兵隊辺野古新基地建設を強行する日本 政府への支持の基盤となってきた。しかし、米 軍は、尖閣諸島での軍事対立に関わらない。米
国の尖閣諸島領有権に対する方針は「中立」で あり、ニクソン政権からオバマ政権まで、これ は一貫している。それに対し、日本では、オバ マ元大統領が、尖閣諸島は日米安全保障条約第 5条の適用範囲であると明言し、また、クリン トン元国務長官も同様の「保証」をしたと言われ てきた。安保第5条は、「日本国の施政の下にあ る領域における、いずれか一方に対する武力攻 撃」がある場合に米国が防衛義務を負うとして いる。日本が実効支配していることが要件であ り、中国が接続水域、EZZ、あるいは領海への 侵入を繰り返しているのは、日本の尖閣諸島に 対する実効支配を無力化する意図があると見ら れている。加えて、米軍関与を保証する条件と して、安保条約第6条に基づき、尖閣諸島の中で、 久場島、大正島という二島が米軍に射爆撃場と して提供されている事実が挙げられている。し かし、久場島 $0.91 \mathrm{~km}^{2}$ 、大正島 $0.04 \mathrm{~km}^{2}$ という 岩礁であり、尖閣最大の魚釣島 $3.64 \mathrm{~km}^{2}$ は含ま れていない。さらに、これらの島嶼が提供され ている根拠である、1972年日米合同委員会・施 設分科会覚書 (「5.15メモ」)に、久場島は「黄尾 嶼」大正島は「赤尾嶼」として記載されている。 「黄尾嶼」「赤尾嶼」は、中国名である。

米国が領有権に関して中立であり、中国語名 称で提供されている尖閣諸島の二島を根拠とし て日本のために対中戦争する、という想定は成 立しない。

\section{（5）海兵隊・オスプレイ}

もし、米海兵隊が尖閣諸島における軍事行 
動を採ると想定しても、海兵隊の実態から、在 沖基地には軍事的意味が小さい。巨額の費用を 投じて自衛隊も導入した米海兵隊の垂直離着陸 「輸送機」MV-22オスプレイが、日本では尖 閣防衛のための「秘密兵器」といった取り上げ られ方をしてきた。しかし、オスプレイは、装 甲の弱い単なる輸送機である。また、オスプレ イにしろ、他の航空機にしろ、海兵隊が展開す るためには、米海軍の強襲揚陸艦に航空機と兵 員を載せ、作戦の現場まで運ばなければならな い。その強襲揚陸艦は、長崎県の米海軍佐世保 軍港におり、沖縄から作戦行動を採るには、海 路 $800 \mathrm{~km}$ 離れた佐世保から強襲揚陸艦を回航す る必要があり、丸一日以上かかる。沖縄が尖閣 諸島に近いことは、海兵隊の作戦行動に関して、 軍事的な意味はない。

2017、18年に、複数の自衛隊の元高官が、相 次いで全国紙紙上で「オスプレイは下から撃た れたらおしまい」「米軍は尖閣での戦闘行為に加 わらない」といった発言をしているのは、今振 り返ると、軍事専門家の間に、この時期から在 沖米軍への期待を下げ、対中「新冷戦」への、日 本による軍事的対応に向ける意図があったのだ ろうと考えられる。

\section{（6）米中新冷戦}

中国の経済成長が、今後どのような道筋をた どるのか、相反する見方が常にある。一つは、 中国が基礎研究、技術開発の領域でも成長を続 け、米国を完全に凌駕するという予測である。 他方、中国のここまでの経済成長は、人口ボー
ナスに依拠する部分が多く、その優位は消尽し た、加えて、研究の自由が無い国で、真の先端 研究はできず、よって、中国も「中進国の罠」か らは逃れられないという予測である。

中国の経済成長が、安全保障、国際関係にど のような影響を与えるかについても、相反する 見方が提示されてきた。一つは、中国の経済成 長は、米国主導の自由主義貿易体制によるもの であり、中国は、この「リベラルな世界秩序」へ の挑戦者とはならないとする。他方、経済成長 により、中国は自国の影響圈を拡大させ、そこ から米国の存在を排除するという「新冷戦論」が ある。現時点で、対中関係楽観論は、力を失っ たように思われる。

現在の習近平政権が、国内的な強権支配と、 対外的な軍事的 - 経済的 - 政治的影響力の拡張 を目指していることは明らかであろう。同時に、 米国トランプ政権による、米国自体のリベラル な世界秩序維持からの撤退、および国内支持獲 得のための対中強硬姿勢が、新冷戦を不可避に していると見られている。仮にトランプ大統領 が再選に敗れても、民主党政権も対中強硬路線 は続けるであろう。「強い中国」と「引き上げる 米国」の中で、日本はどのような将来を見据え るのか。

\section{（7）沖縄への含意}

尖閣諸島をめぐる潜在的紛争の意味は、「米 中新冷戦」の高まりの中で、根本的に変えられ ようとしている。宮古島、石垣島、与那国島に、 自衛隊基地が建設され、あるいは建設されつつ 
ある。既に完成した与那国島の陸上自衛隊駐屯 地は、中国艦船を監視するレーダー基地である が、現在建設中の宮古、石垣両島の基地（写真 1、2）は、所謂、第一列島線を通り太平洋に出 る中国海軍艦船を攻撃するための地対艦ミサイ ル基地である。沖縄島と宮古島の間の宮古海峡 は、日本の排他的経済水域には含まれるが、基 本的に公海であり、日本が中国艦船に対して攻 撃する法的根拠を持たない。8月に自民党が首 相に提言した、敵基地攻撃能力の保持とは次元 が異なるとはいえ、中国艦船に向けた攻撃基地

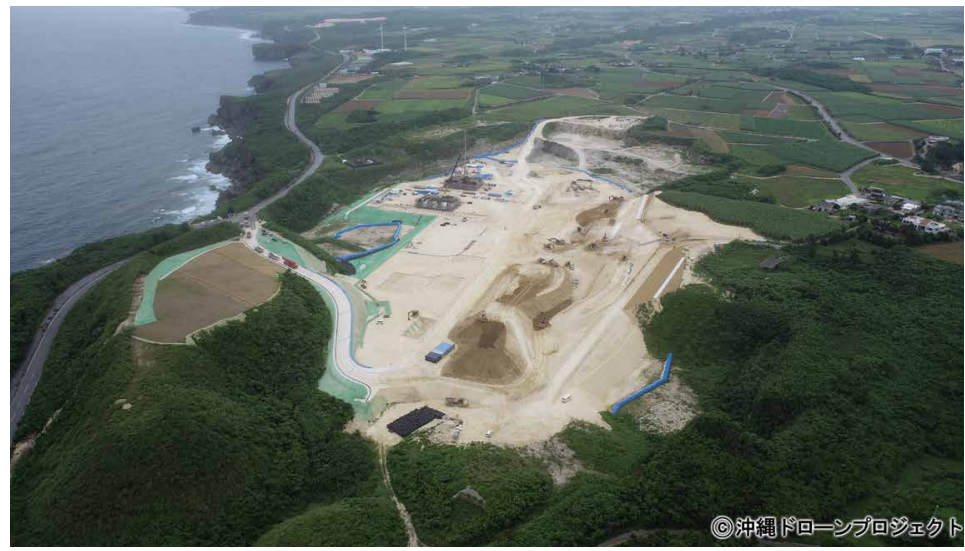

写真1 陸上自衛隊弾薬庫建設現場（宮古島市保良地区） 2020年6月 22 日撮影。「沖縄ドローンプロジェクト」提供。



写真2 陸上自衛隊ミサイル基地建設現場（石垣市平得大俣地区） 2020 年 6 月 24 日撮影。「沖縄ドローンプロジェクト」提供。
が自衛隊の下で造られている。日本政府は、こ れら基地で米国に代わる攻撃能力を持つことで、 米国を引き込む、引き留めることを狙っている と見られる。

しかし、米国が、中国との全面戦争に繋がる 可能性がある軍事紛争に加わることは考えられ ない。むしろ、宮古島、石垣島は、日本にとっ ても中国にとっても米国にとっても「都合の良 い」戦場とされる危険性が高い。遠隔離島であ り、国家中心部から遠い、仮に軍事衝突が起き ても、際限ないエスカレーションが無い限り、 戦闘被害は島々に限定される。日本 が代理戦争をした上で、何らかの「手 打ち」となる、そのようなシナリオ が想定されているのではないか。

米海兵隊が、2020年3月に発表 した、今後の組織・戦力再編計画 「戦力デザイン 2030」を基に、デイ ヴィッド・バーガー海兵隊総司令官 が7月のロイター通信への取材で明 らかにした構想が、「海兵沿岸連隊」 の設立である。これは、海兵隊が中 国の艦船を攻撃するために、海軍と の統合作戦を進める一方、総兵員数、 航空機部隊、砲兵部隊の削減を実施 する、というものである。この沿岸 連隊の配備地として、ハワイ、グア ムと並び沖縄が計画されている。駐 留するだけの演習部隊であった在沖 海兵隊が、海戦を主要任務とする戦 隊に転換されようとしている。自衛 
隊の南西シフトは、これに連動しており、沖縄 が直接の軍事衝突に巻き込まれる危険性は、一 層高まっていく。海兵隊は、常に存在意義を問 われてきた。実戦の可能性が下がれば、人道支援・ 災害救援を前面に出し、中国の圧力が高まれば 離島奪還を売りにする。それが、遂に海戦であ る。米軍にとり、敷居の低い戦闘領域であろうが、 当事者にされる沖縄にとっては、大焱難になり うる。

宮古・石垣に合計 10 万人以上の住民がいる。 軍事衝突が起きた時に、彼らを避難させる方法 はない。沖縄は、あらゆる手段で軍事的緊張を 緩和させ、再び戦場にされることを阻止しなけ ればならない。ここまでの西側の中国との経済 統合は、緊張緩和に繋がらなかった。今後も困 難だろう。しかし、市民レベルの繋がりを構築 する努力は、まだ十分になされていない。習近 平主席の国賓来日は、先行き不明だが、少なく とも、現時点でそれが緊張激化への抑制条件と なっている事実は評価しなければならない。米 国に屈服してきた代わりに、中国に屈服する、 というような思考ではなく、また、中国を見下 すことで居場所を見いだした気になる思考でも なく、米国を通さずに、まともに一つの国と向 き合う営為を、戦後初めてしなければならない。 沖縄は、共存追及の「場」にならねばならない。 戦場に、ではなく。
参考文献

ニつの言説に関して、楽観論は、例えば『沖縄県アジア経済戦 略構想推進計画 (平成28年)』、危機論は『防衛白書令和2 年版』、

米国の尖閣諸島政策については、Mark E. Manyin, ”The Senkakus (Diaoyu/Diaoyutai) Dispute: U.S. Treaty Obligations", Congressional Research Service Reports, October 14, 2016、https://fas.org/sgp/crs/row/R42761.pdf 尖閣での軍事衝突可能性については、Michael E. O'Hanlon, "The Senkaku Paradox: Risking Great Power War Over Small Stakes", Brookings Institution Press, 2019。

久場島（黄尾嶼）、大正島（赤尾嶼）の施設提供に関しては、 外務省『地位協定第 25 条に基づいて設置された合同委員会 第251回会合議事録（仮訳）』1972年5月15日、pp. 185188 。

元自衛隊高官インタビューは、以下の通り。佐藤正久、朝日新 聞福岡版2017年2月 25 日、香田洋二、朝日新聞2017年8 月 23 日、杉本正彦、朝日新聞2017年12月19日、山口昇、 朝日新聞2018年12月 6 日。

辺野古新基地建設の新たな問題点は、北上田毅「軟弱地盤問題 の意味するところ」、豊下楢彦他編『沖縄を世界軍縮の拠点 に』岩波書店、2020年参照。

対中「楽観論」の代表的論考が、G. John Ikenberry, “The Rise of China and the Future of the West: Can the Liberal System Survive?" Foreign Affairs, January/February, 2008。

「新冷戦論」に一定の信憑性を付与したのが、Graham Allison, "Destined for War: Can America and China Escape Thucydides's Trap?", Scribe, 2017である。

中国の現状については、益尾知佐子『中国の行動原理』中央公 論新社、2019 と梶谷懐・高口康太『幸福な監視国家・中国』 NHK出版、2019が有用である。

領海については、海上保安庁『管轄海域情報〜日本の領海〜』 https://www1.kaiho.mlit.go.jp/JODC/ryokai/ryokai.html

米海兵隊組織・戦力改編については、USMC "Force Design 2030" https://www.hqmc.marines.mil/Portals/142/Docs/ CMC38\%20Force\%20Design\%202030\%20Report\%20 Phase\%20l\%20and\%20ll.pdf?ver=2020-03-26-121328-460 